\title{
Implementation of physical, sports, and health education facilities
}

\author{
Jutri Dayanti*, Sumaryanto, Fitri Agung Nanda \\ Yogyakarta State University. Colombo Street No. 1 Yogyakarta, 55281, Indonesia \\ * Corresponding Author. Email: jutrid72@gmail.com
}

Received: Juni 16, 2020; Revised: September 2, 2020 ; Accepted: September 9. 2020

\begin{abstract}
To the physical, sports, and health education, facilities have been one of the factors that support the successful assessment of learning results. with reference to the statement, the conduct of the study aims at identifying the implementation of Physical, Sports, and Health Education facilities management. During the conduct of the study, the subjects that had been selected were the Physical, Sports, and Health Education teachers and the School Principals of State 26 Elementary School and State 89 Elementary School in the City of Bengkulu. Then, the nature that had been adopted for the study was the qualitative research and the data were gathered by means of observation. During the observation, the notes on the condition, the inventory, the maintenance, and the implementation of the facilities management were collected. The results of the study show that the management of Physical, Sports, and Health Education facilities has not been properly implemented. The results have been confirmed by the following findings: (1) the condition of the existing Physical, Sports, and Health Education facilities is not fit for operation anymore; (2) the number of the Physical, Sports, and Health Education facilities is unfit; (3) the inventory for the Physical, Sports, and Health Education facilities is not properly implemented; (4) the awareness for maintaining the Physical, Sports, and Health Education facilities are low; and (5) the removal of the Physical, Sports, and Health Education is not implemented yet.
\end{abstract}

Keyword: management, facilities, physical, sports, health education

How to Cite: Dayanti, J. Sumaryanto \& Nanda, F. A. (2021). Implementation of physical, sports, and health education facilities. Jurnal Keolahragaan, 9(1), 26-34. doi:https://doi.org/10.21831/jk.v9i1.32490

\section{INTRODUCTION}

The process of physical, sports, and health education benefits the physical activities that have been planned systematically in order to develop and to improve individuals organically, neuromuscularly, perceptually, cognitively, and emotionally under the framework of the national education system (Rosdiani, 2013). According to Tesfaye and Deol (2016), Physical, Sports, and Health Education is the most important subject in the school in relation to the students' interest in the curriculum because this subject serves as the departure point for the students who want to be actively involved in the physical activities. Similarly, Ho et al. (2018) explains that the well-qualified implementation of Physical, Sports, and Health Education involves a number of developmental aspects in the education such as content knowledge in sports, curriculum, teaching and assessment, and also supporting factors development. The supporting factors development themselves consist of training ground, professional personnel training programs, extended learning opportunity, inclusion policy, and gender balance and equality in the education. In relation to the statement, Husdarta (2011) states that in order to be a good teacher of Physical, Sports, and Health Education there are five fundamental skills that should be possessed namely: (1) appreciation toward the philosophical foundation of the profession and of the professional attitude; (2) ability to implement the principles and theories from the Sports Science into the mentoring practice; (3) ability to perform the Sports or to understand the movement function; (4) teaching-learning process management; and (5) social skills including the leadership. Based the opinions by the above experts, it might be concluded that Physical, Sports, and Health Education is an important part of overall education that involves numerous development aspects namely the cognitive aspects, the affective aspects, and the psychomotor aspects. Nugroho, Kristiyanto, \& Doewes, (2018) explain that physical education is a learning program that provides proportional and adequate attention to the realm of learning, namely psychomotor, cognitive, and affective. Furthermore, it was explained that in physical 
education learning the importance of paying attention to the curriculum, facilities to support the success of learning.

Speaking about the psychomotor aspects, the psychomotor aspects is an important part in the learning process of Physical, Sports, and Health Education and has close association to both the learning tools and the learning media that should be utilized in the learning process. In the Physical, Sports, and Health Education, these tools or media are known as facilities. In this regard, the sports facilities should meet the sports standards. According to Law Number 3 of 2005 on National Sports System CHAPTER XI Article 67 Verse 68, the standards of sport facilities consist of the engineering standards, the health standards, and the safety standards. In terms of the engineering standards, the sports facilities should meet the special standards that have been defined by both the headquarter and the branch unit of the sports federations. These engineering standards cover the aspects of size, form, and type. Then, in terms of the health standards, the sports facilities should meet the minimum health standards that have been defined. Next, in terms of the safety standards, the sports facilities should meet the minimum standards of safety that have been defined. Departing from these standards, it is clear that the Physical, Sports, and Health facilities should be well-maintained in order to support the success of the learning process. Consequently, there should be good management of the facilities maintenance since facilities management serves as the supporting function within an organization or an educational institution (Jensen, 2017). In this regard, facilities management might be defined as a coordination that strives to support the work effectiveness in order to achieve the intended objective (Kok, Mobach, \& Omta, 2011). The objective of management facilities is to set and monitor the financially and environmentally safe and secured maintenance and operationalization of the sports facilities (Schwarz, 2010).

The implementation of Physical, Sports, and Education facilities management refers to the general activities of educational facilities management with more specific attention that should be given to the sports facilities. As having been explained by Harsuki (2012), sports facilities management refers to the process of planning, administering, coordinating, and assessing the daily implementation of the sports facilities. The statement has been asserted by the Directory of Teaching Staffs the Department of National Education (2007), which states that facilities management is expected to assist the schools in planning the needs of the facilities, in managing the procurement of the facilities, in managing the maintenance of the facilities, in managing the inventory of the facilities, and in managing the removal of the facilities. Unfortunately, the discussion over the sports facility management is still a taboo among the teachers of Physical, Sports, and Health Education whereas if a teacher of Physical, Sports, and Health Education is able to implement the facilities management well then the learning process will be better conducted. In a similar tone, (Asiabaka, 2008) explains that good facilities management can assist the teaching-learning process. At the same time, Rahman (2017) explains that the good facilities maintenance should be implemented in order to support the success of the learning process (Putri Isnaeni Kurniawati, 2013). The procurement of facilities, which is always conducted at the end of each year, should be performed by analysing the necessary needs under the semester planning or the annual planning with attention given to the available budget. Furthermore, the school facilities maintenance should be performed under regular and daily basis in order to prevent any damage. According to Ismail et al. (2016), there should be teacher awareness in performing the facilities maintenance in order that problems due to the damage and the inappropriate planning might be avoided for the procurement of each facility. By doing so, it is possible that the good facilities will support the learning process.

Departing from the above elaboration on the problems, it might be identified that the Physical, Sports, and Health facilities management by the teachers is important and compulsory. With the presence of the good Physical, Sports, and Health facilities, these facilities will be able to provide maximum contribution toward the achievement of the Physical, Sports, and Health Education learning objectives and the attainment of Sports achievements. At the same time, the conditions of the Physical, Sports, and Health Facilities will always be in order, well-maintained, and ready to use. Assessing from the overall situation, the focus of the present study will be on the Physical, Sports, and Health Education facilities in the State Elementary Schools located in the City of Bengkulu since there has not been any study that uncovers the facilities maintenance by the teachers of Physical, Sports, and Health Education. 


\section{METHOD}

This research is a qualitative study that aims to find out and find information and a description of the implementation of the management of public elementary school physical education facilities and infrastructure in Bengkulu City. This research was conducted in October-November 2018 at SD Negeri 26 Bengkulu City and SD Negeri 89 Bengkulu City. The subjects of this study were two school principals and two teachers of Physical Education, Sports, and Health from two SDNs, namely SD Negeri 26 and SD Negeri 89 in Bengkulu City. Data collection techniques in this study were to use observation instruments, interviews, and documentation conducted at SD Negeri 26 and SD Negeri 89 in Bengkulu City. The data analysis technique is a qualitative data analysis technique. In qualitative research, data analysis is carried out before visiting the research location, during the visit, or after the visit. Data analysis was carried out by collecting data, reducing data, presenting data, and drawing conclusions.

\section{RESULT AND DISCUSSION}

\section{Result}

After observing the management of Physical, Sports, and Health Education facilities in the two selected state elementary schools from the City of Bengkulu, several problems had been found. These problems might be elaborated as follows.

First, the Physical, Sports, and Health Education facilities were not fir for operation anymore. The statement was confirmed by the following conditions: (a) the soccer ball had been ripped off; and (b) the mattress for the gymnastics had been torn. The two conditions were found during the observation toward the learning process led by the teachers of the Physical, Sports, and Health Education.

Second, the number of Physical, Sports, and Health Education facilities was insufficient. The insufficient number of Physical, Sports, and Health facilities certainly hinder the teaching-learning process of the Physical, Sports, and Health Education facilities. Then, the complete data on the insufficient number might be consulted in Table 1 and Table 2.

Table 1. List of Physical, Sports, and Health Education Facilities in the State 26 Elementary School, the City of Bengkulu

\begin{tabular}{|c|c|c|c|c|}
\hline \multirow{2}{*}{ No. } & \multicolumn{2}{|c|}{ Sports Facilities } & \multicolumn{2}{|c|}{ Sports Facilities } \\
\hline & Type & Number & Type & Number \\
\hline 1. & Field & 1 & Athletic Kit & 3 packages \\
\hline 2. & & & Shot Put & 0 \\
\hline 3. & & & Baton & 16 \\
\hline 4. & & & Futsal Ball & 3 \\
\hline 5. & & & Futsal Goal & 2 \\
\hline 6. & & & Soccer Ball & 5 \\
\hline 7. & & & 50-cm cylindrical cone & 0 \\
\hline 8. & & & $25-\mathrm{cm}$ cylindrical cone & 10 \\
\hline 9. & & & Round cone & 0 \\
\hline 10. & & & Gymnastic mattress & 2 \\
\hline 11. & & & Base Ball & 2 tubes \\
\hline 12. & & & Batter & 2 \\
\hline 13. & & & Table for Table Tennis & 0 \\
\hline 14. & & & Table Tennis Net & 0 \\
\hline 15. & & & Paddle & 0 \\
\hline 16. & & & Badminton Racket & 8 \\
\hline 17. & & & Badminton Net & 2 \\
\hline 18. & & & Shuttlecock & 1 tubes \\
\hline 19. & & & Ball for Kick Volleyball & 2 \\
\hline 20. & & & Net for Kick Volleyball & 1 \\
\hline 21. & & & Ball for Volley Ball & 2 \\
\hline 22. & & & Net for Volley Ball & 2 \\
\hline
\end{tabular}


Jurnal Keolahragaan 9 (1), 2021 - 29

Jutri Dayanti, Sumaryanto Sumaryanto, Fitri Agung Nanda

Table 2. List of Physical, Sports, and Health Education Facilities in the State 26 Elementary School, the City of Bengkulu

\begin{tabular}{|c|c|c|c|c|}
\hline \multirow{2}{*}{ No } & \multicolumn{2}{|c|}{ Sports Facilities } & \multicolumn{2}{|c|}{ Sports Facilities } \\
\hline & Type & Number & Type & Number \\
\hline 1. & Field & 1 & Athletic Kit & 1 package \\
\hline 2. & & & Shot Put & 0 \\
\hline 3. & & & Baton & 6 \\
\hline 4. & & & Futsal Ball & 2 \\
\hline 5. & & & Futsal Goal & 2 \\
\hline 6. & & & Soccer Ball & 3 \\
\hline 7. & & & 50-cm cylindrical cone & 0 \\
\hline 8. & & & 25-cm cylindrical cone & 6 \\
\hline 9. & & & Round cone & 0 \\
\hline 10. & & & Gymnastic mattress & 2 \\
\hline 11. & & & Base Ball & 1 tube \\
\hline 12. & & & Batter & 2 \\
\hline 13. & & & Table for Table Tennis & 1 set \\
\hline 14. & & & Table Tennis Net & 1 \\
\hline 15. & & & Paddle & 4 \\
\hline 16. & & & Badminton Racket & 0 \\
\hline 17. & & & Badminton Net & 0 \\
\hline 18. & & & Shuttlecock & 0 \\
\hline 19. & & & Ball for Kick Volleyball & 0 \\
\hline 20. & & & Net for Kick Volleyball & 0 \\
\hline 21. & & & Ball for Volley Ball & 3 \\
\hline 22. & & & Net for Volley Ball & 0 \\
\hline
\end{tabular}

The data in the above tables show that the Physical, Sports, and Health Facilities that the State 26 Elementary School and the State 89 Elementary School in the City of Bengkulu have been limited. Therefore, the two elementary schools should carry out necessary planning and procurement for these facilities.

Third, the inventory on the Physical, Sports, and Health Education has not been well implemented. This finding has been confirmed by the absence of the inventory book of these facilities, which should be held by the teacher of Physical, Sports, and Health Education. Consequently, during the observation manual calculation activities should be performed in order to directly confirm the number of the Physical, Sports, and Health Education activities.

Fourth, the awareness on the maintenance of the Phyics, Sports, and Health Education has been low. This finding is apparent from the situations that have been found at the end of the learning proces. For example, after the learning process has ended the sports facilities that have been used are not kept in the inventory room but, instead, these facilities are kept under the table and above the cupboard.

Fifth, the removal of Physical, Sports, and Health facilities has not been implemented. This finding is apparent from the fact the already insufficient Physical, Sports, and Health Education facilities are still in use during the learning process

\section{Discussion}

Departing from the results of the study that uncover the obstacles and the lack of implementation on the part of Physical, Sports, and Education facilties management, there are several points of concordance with both of the theories and the results of the studies that have previously been conductedon the facilities management. For example, the results of a study by Asiyai (2012) show that the school facilities in general are found in damaged conditions. Furthermore, in this study Asiyai (2012) suggests that the maintenance that has been implemented is still insufficient for most of the school facilities. Then, the factors that promote the termination on the use of the school facilities include overloading and maintenance postpone on the facilities. In this regard, the administrator should play more significant role in the school facility management and maintenance especially in the regular facility inspection and the maintenance decentralization. As a result, the government should assure that sufficient number of facilities are available for the schools in order to meet the number of the already registered students. Such assurance is highly necessary since it is possible that most of the schools 
facilities have been broken. Therefore, it is deemed important for the educational planner and the school leadership to reconstruct, rennovate, reinforce, and replace several main components. At the same time, the school administrators, the teachers, and the students should develop and internalize the culture of good facility maintenance. The reason is that the maintenance cost is quite expensive and, consequently, the educational planners and the policymakers should assure that the needs toward facility procurement is sufficient to be inputted into the facility management and maintenance. Not to mention, the technology cost has been high as well nowadays. Due to this situation, more fund should be allocated to the schools in the oil-producing regions of a country in order to cover the gap in the school facility management and maintenance. Moreover, the facilities that have not been well maintained might be broken within a relatively short period of time and, as a consequence, preventive maintenance procedures should be assigned and be implemented by the school manager.

As an example of good sports facilities managemen, the sports high schools that hold the programs of Sports Education in the Region of Central Anatolia have been opened prior to the completion of the the infrastructure construction. The sports facilities in these sports high schools serve to provide sports training programs despite the insufficient number of personnel and facilities in terms of quality and quantity. Consequently, it might be concluded that the lack of sports facilities might decrease the quality of the training programs. As a response to this situation, it might be proposed that the sports high schools should not be opened until the infrastructure, namely the sports facilities, the sports equipment, and the sports personnel, has been ready (Nacar, Gacar, Karahüseyİnoğlu, \& Gündoğdü, 2013). In relation to this situation, there are two factors that might influence the decisionmaking process among the parents namely: (1) the school facilities; (2) Physical Education; and (3) sports activities. The results of a study by (Alsuiadi, 2016), in this context, compare the level of interest among the parents toward the facilities that have been available in the public schools and the private schools. The parents consider that the private schools are more prominent than the public schools in terms of Physical Education and sports activities (Alsuiadi, 2016).

With reference to the above example, in their study Mulida et al. (2016) state that the management of sports facilties that the School Principal of State 5 Senior High School Banca Aceh has implemented includes procurement, which is one of the efforts for providing the facilities by means of purchase, rent, borrow, trade, and recycle within the manufacture of the sports tools and equipment in accordance to the needs of the school. In this regard, equal distribution is an action that should be openly and transparently carried out in order to overcome the problems that the school experience. The problems that the school experience might be associated to the ones that lie in the match between the facilities beneficiary and the equal distribution agenda. In spite of these problems, the utilization of the facilities has headed toward the process of objective achievement. Then, the regulatory process of inventory, storage, and maintenance by the School Principal of the State 5 Senior High School Banda Aceh in relation to the educational facilities management consists of archiving the number of edudcational facilities into an inventory list, composing reports, and improving knowledge and supervision among the school employees with regards ti the planning of the procurement plan, the facilities operationalization, and the maintenance.

Pukīte and Geipele (2017) explain that management refers to the activity that leads to the inflow cash of an object or also known as money in. However, with regards to facilities management, maintenance ensures the healthy function of a project for a longer period of time under more affordable cost or also known as money out. Maintenance indeed has a wide operation and becomes one of the numerous exploitation processes with quite specific duty and function. An accurate management demands knowledge and especially-skilled expertise. On the other hand, a good management appears when the operation that has been performed is transparent and reliable, when there are regular report and participation, and when there is rapid response toward the needs and the complaints of the customers. The whole process intensive time and expensive knowledge. During the managerial process, the property owners should solve several problems such as how to implement building management effectively and in accordance to the existing regulations. These owners should select the most appropriate and acceptable management type in terms of economy. Similarly, Nawi et al. (2017) state that both government organizations and non-government organization in Malaysia should pave their own way in developing the professional organizations in terms of facility management. Furthermore, the results of their study show that the problems of health and safety in construction are highly significant for management especially for the Malaysian industries. 
Kurniawan (2018) explains that during the conduct of his study, the classrooms have suffered frolm 13.33 - 26.67\% damage, which might be categorized as "Low Damage," and yet the remaining parts of these classrooms might be used. Then, the supporting aid or media is fit for utilization but, unfortunately, most of the computer units in the school have been out of order and the damage of these computer units have ranged between $40 \%$ and $60 \%$. With reference to this situation, it is clear that good facilities are one of the aspects that should be given attention and should be maximized in order to improve the effective of the learning process of Al-Firdaus Kindergarten. Furthermore, the results of a study by Hajrawati (2013) show that the facilities management that has been implemented in the State 1 Vocational High School includes three domains namely: (1) learning facilities management; (2) facilities standardization, which has not been in accordance to the support of the good quality-based learning process; and (3) procurement of learning facilities. Specific to the third domain, the low budget for procuring the needs toward the facilities and the limited space that might be benefitted for storing the facilities that will be operated become the discouraging factors for the facilities procurement while the willingness of both the teachers and the students to afford the procurement of these facilities and the available budget for the procurement become the encouraging factors for the facilities procurement.

The results of a study by Adiele and Morgan (2018) show that sports facilities and equipment management might be abandoned by the City Board of Kwekwe. Furthermore, through the results of the study they show that there has not been any regular supervision and inspection toward the sports facilities and equipment available in the City Board of Kwekwe. The insufficient space for storing the portable sports facilities and equipment have resulted in the damage of these sports facilities and equipment. At the same time, the results of their study also show that the sports facilities and equipment management has been under the appropriate standards, the inspection has been irregular, and the sports facilities and equipment has been conducted prior to the compettion. Consequently, the athletes are exposed to the danger of injury and infection. However, the school facilities and infrastructures play an important role in drawing the students' interest. With regards to the statement, the insufficient condition of the school facilities in the Amal Saleh Kindergarten has impacted the figure of the students' enrollment (Alkadri, Ningrum, Santoso, \& Afriansyah, 2018).

On the other hand, the results of a study by Arslan (2010) have served as a matter of reference in improving and evaluating the sports facilities management in a campus. Unfortunately, the results of his study show that the sports facilities in the campus have been in less relevance to the number of the university students. Not to mention, other weaknesses have also been found based on the results of the evaluation within the study. These weaknesses might be elaborated as follows: (1) some sports are less popular and consequently the facilities of these sports receive less attention; (2) the number of skillful coaches has been insufficient; (3) there is separated space for the female sports; and (4) the sports budget has been low. In response to these findings, Wan-Hamdan et al. (2011) state that the evaluation results that display in relation to the preliminary study serve as a matter of reference for the facilities in the educational institutions so that the managerial function of higher education might be strengthened in terms of strategic planning; in turn, the strategic planning might be better. Indeed, evaluation becomes one activity that should be routinely conducted in order assure the quality of the existing facilities. Bogar (2008) has studied he trend in the construction and the design of the recreational sports facilities in the higher education of the United States of America. Furthermore, Bogar (2008) has also analysed the number of sports facilities that have been reconstructed so that these facilities might have dual functions. As a result, the newly constructed facilities might support the functions such as the academic, the health, the fitness, and the sports functions. At the same time, these recreation sports facilities also contain unique features such as climbing wall, rooftop playground, catering service, counselling centre, department stores, and campus police departments.

Londhe (2013) states that the evaluation of sports facilities that has been implemented is already sufficient but there are several aspects that have received less in-depth evaluation. Therefore, it is suggested that the management board of the sports facilities should be able to maximize the aid that has been delivered in order to maintain the sports facilities well. Indeed, the sports facilities require in-depth attention and evaluation within the already defined deadline in order to support the achievement of the athletes by means of well-qualified sports facilities. In relation to the statement, Isa et al. (2016) suggests that the implementation of the facilities management shows different results depending on the perspective on the various geographical locations, interests, and schools of thought. The facilities management delegates the service-based industry to the expert consultants and the facility 
administration of the clients' buildings, including the settlement, the commercial compounds, the industrial compounds, the airports, the bus statons, and the office buildings. In relation to the statement, Ekuri (2018) explains that certain sports such as Athletics, Lawn Tennis, Table Tennis, Marathon, Squash, and Swimming are provided with sufficient facilities in the states, while other sports such as Judo, Boxing, Wrestling, and Weight Lifting are only provided with the sufficient facilities in the central office of the states. In the meantime, the facilities for the sports such as Taekwondo, Volleyball, Cricket, Badminton, Soccer, Cycling, Hockey, and Basketball are not provided with sufficient facilities in both levels. The equipment quality in the Cross River States sports has been very low as well, as having been confirmed by the results of the study.

Lindsey et al. (2009) conducted a study on the impact of Campus Recreation Sports Facilities and Recruitment and Retention Programs among the African-American students. The aim of their study is to assess the impact of the recreation sports programs and facilities on the recruitment and the retention of both the male and the female African-American students. The results of their study show that $60 \%$ of the male African-American students who have been surveyed report the significance of the recreation sports facilities availability in attending the course while $68 \%$ of the male African-American students who have been surveyed report the significance of the recreation sports facilities availability in making the decision to continue attending the course. In this study, the male African-Amerian studies earn higher score than the female counterparts with regards to the significance of the recreation sports programs and facilities availability in making decisions to continue their study and in making decisions with regards to the importance the recreation sports activities that they will have after the graduation and als to the total weekly time allocation for their participation in the active recreation sports facilities. In relation to the statement, Adiele and Morgan (2018) suggest that the sports facilities that have been utilized are insufficiently installed and maintained. The insufficient space for strong the facilities, especially the non-portable sports facilities, might result in the damage of the facilities due to the improper utilization. The results of this study indicate the sub-standards of the sports facilities and equipment utilization and the irregular sports facilities and equipment inspection and maintenance prior to the competition. As a result, the athletes become exposed to the dangers of injury and infection.

\section{CONCLUSION}

Based on the results of the study, it might be concluded that both the school principals and the teachers of Physical, Sports, and Health Education have not implemented the Physical, Sports, and Health facilities management. Then, there are several aspects that have been observed namely: (1) the condition of the existing Physical, Sports, and Health Education facilities is not fit for operation anymore; (2) the number of the Physical, Sports, and Health Education facilities is unfit; (3) the inventory for the Physical, Sports, and Health Education facilities is not properly implemented; (4) the awareness for maintaining the Physical, Sports, and Health Education facilities is low; and (5) the removal of the Physical, Sports, and Health Education is not implemented yet.

\section{REFERENCE}

Adiele, D., \& Morgan, G. D. P. (2018). Assessing Management Practices of Sport Facilities and Equipment by the Municipality Council. International Journal of Science and Healthcare Research, 3(2), 44-49.

Alkadri, H., Ningrum, T. A., Santoso, Y., \& Afriansyah, H. (2018). Essentiality of Management of Facilities and Infrastructure toward a Number of Students of Early Years Institution. Atlantis Press, (January). https://doi.org/10.2991/icece-17.2018.18

Alsuiadi, F. (2016). Effect of the School Facilities Factor and Sport Activities Factor on Parents in terms of Private and Public School Choice at Riyadh City Saudi Arabia. Universal Journal of Educational Research, 3(12), 1054-1069. https://doi.org/10.13189/ujer.2015.031215

Arslan, D. (2010). Research information and recommendations to improve sports facilities in university. Thesis report submitted to the Superior University Lahore.

Asiabaka, I. P. (2008). The Need for Effective Facility Management in Schools in Nigeria. New York Science Journal, 1(2), 10-21. 
Asiyai, R. (2012). Assessing School Facilities in Public Secondary Schools in Delta State, Nigeria. African Journals, 6(2), 192-205. https://doi.org/10.4314/afrrev.v6i2.17

Bogar, C. (2008). Trends in Collegiate Recreational Sports Facilities. The Sport Journal, 11(4), 1-9.

Ekuri, P. E. (2018). Standard Facilities and Equipment as Determinants of High Sports Performance of Cross River State at National Sports Festival. Journal of Public Administration and Governance, 8(2), 48. https://doi.org/10.5296/jpag.v8i2.13177

Hajrawati, H. (2013). Manajemen sarana dan prasarana pembelajaran berdasarkan standar nasional. Jurnal Eklektika, 1, 137-152.

Harsuki, H. (2012). Pengantar manajemen olahraga. Jakarta: PT Raja Grafindo Persada.

Ho, W., Ahmed, M. D., D’Amico, R. L. de, Ramos, A., Ferreira, E. L., Ferreira, M. B. R., ... Wong, B. (2018). Measuring the perception of quality physical education in Latin American professionals. Revista Brasileira de Ciencias Do Esporte, 40(4), 361-369. https://doi.org/10.1016/j.rbce.2018.05.006

Husdarta, H. J. S. (2011). Manajemen pendidikan jasmani. Bandung: Alfabeta.

Isa, N. M., Kamaruzzaman, S. N., Mohamed, O., Jaapar, A., \& Asbollah, A. Z. (2016). Facilities Management Practices in Malaysia: A Literature Review. In MATEC Web of Conferences (Vol. 00054, pp. 1-7).

Ismail, Z., Mutalib, A. A., \& Hamzah, N. (2016). A Case Study of Maintenance Management Systems in Malaysian Complex and High-rise Industrialized Building System Buildings. International Journal of Economics and Financial Issues, 6, 28-35.

Jensen, P. A. (2017). Strategic sourcing and procurement of facilities management services. Journal of Global Operations and Strategic Sourcing, 10(2), 138-158. https://doi.org/10.1108/JGOSS-102016-0029

Kok, H. B., Mobach, M. P., \& Omta, O. S. W. F. (2011). The added value of facility management in the educational environment. Journal of Facilities Management, 9(4), 249-265. https://doi.org/10.1108/14725961111170662

Kurniawan, N. (2017). Pengaruh Standart Sarana Dan Prasarana Terhadap Efektifitas Pembelajaran Di Tk Al-Firdaus. Jurnal Pendidikan Dan Pembelajaran Anak Usia Dini, 2(2), 14.

Lindsey, R., Sessoms, E., \& Willis, G. (2009). Impact of Campus Recreational Sports Facilities and Programs on Recruitment and Retention among African American Students: A Pilot Study. Recreational Sports Journal, 33(1), 25-34. https://doi.org/10.1123/rsj.33.1.25

Londhe, D. N. (2013). A study of sports facilities in the colleges of Nashik City. IOSR Journal of Humanities and Social Science, 10(3), 43-46. https://doi.org/10.9790/0837-01034346

Mulida, M., Murniati, M., \& Niswanto, N. (2016). Manajemen sarana dan prasarana pendidikan pada SMA Negeri 5 Banda Aceh. Jurnal MUDARRISUNA: Media Kajian Pendidikan Agama Islam, 6(1), 135-142. https://doi.org/10.22373/jm.v6i1.901

Nacar, E., Gacar, A., Karahüseyİnoğlu, M. F., \& Gündoğdü, C. (2013). Analysis for Sports Facilities in Sports High School in terms of Quality and Quantity [ Central Anatolia Region Sample ]. Australian Journal of Basic and Applied Sciences, 7(2), 627-631.

Nasrun, M., Nawi, M., Baharum, F., \& Ibrahim, S. H. (2017). A Review Study of Maintenance and Management Issues in Malaysian Commercial Building towards Sustainable Future Practice. In AIP Conference Proceedings (Vol. 020100).

Nugroho, K. A., Kristiyanto, A., \& Doewes, M. (2018). Implementasi pendidikan jasmani dalam international primary curriculum. Jurnal Keolahragaan, 6(2), 110-119. https://doi.org/10.21831/jk.v0i0.21336

Puķīte, I., \& Geipele, I. (2017). Different Approaches to Building Management and Maintenance Meaning Explanation. Procedia Engineering, 172, 905-912. https://doi.org/10.1016/j.proeng.2017.02.099

Putri Isnaeni Kurniawati, S. A. S. (2013). Manajemen sarana dan prasarana di SMK N1 Kasihan Bantul. Jurnal Akuntabilitas Manajemen Pendidikan MANAJEMEN, 1, 98-108. 
Jurnal Keolahragaan 9 (1), 2021 - 34

Jutri Dayanti, Sumaryanto Sumaryanto, Fitri Agung Nanda

Rahman, Y. (2017). Pengelolaan sarana prasarana di smp kanisius pakem. Jurnal Hanata Widya, 6, $100-107$.

Rosdiani, D. (2013). Model Pembelajaran Langsung Dalam Pendidikan Jasmani Dan Kesehatan. Bandung: Alfabeta.

Tesfaye, H., \& Deol, N. S. (2016). Analytical study of attitude and infrastructure of physical education / sport in Addis Ababa, Ethiopia. International Journal of Physical Education, Sports and Health, 3(6), 334-337.

Wan-Hamdan, W. S. Z., Hamid, M. Y., \& Mohd-Radzuan, N. A. (2011). Contribution of facilities management processes in supporting Malaysia National Higher Education Strategic Plan. Procedia Engineering, 20, 180-187. https://doi.org/10.1016/j.proeng.2011.11.154 